INTERDISCIPLINARIA ARCHAEOLOGICA NATURAL SCIENCES IN ARCHAEOLOGY

\title{
Abies alba and Homo sapiens in the Schwarzwald - a Difficult Story
}

\author{
Manfred Rösch ${ }^{a^{*}}$ \\ ${ }^{a}$ Laboratory of Archaeobotany, Regional Heritage Institute Baden- Württemberg, Fischersteig 9, 78343 Gaienhofen-Hemmenhofen, Germany
}

\section{ARTICLE INFO}

\section{Article history:}

Received: $11^{\text {th }}$ March 2015

Accepted $4^{\text {th }}$ September 2015

\section{Keywords:}

northern Schwarzwald

cirque lakes

national park

vegetation history

natural forest

\begin{abstract}
$A B S T R A C T$
High-resolution pollen profiles from the centres of all the cirque lakes of the northern Schwarzwald give new evidence on the forest and landscape history of the Schwarzwald National Park and its vicinity during the last six millennia. In the early $4^{\text {th }}$ millennium, Abies alba became the most frequent tree of the mountain forest; it had invaded the region several centuries earlier together with Fagus sylvatica. The trees replaced were Quercus, Ulmus, Tilia, Fraxinus, and Corylus. The first human impact occurred towards the end of the $4^{\text {th }}$ millennium: small-scale deforestation, followed by reforestation - starting with Betula. As a consequence, Fagus increased and became more frequent than Abies. In spite of heavy human impact and clearances, especially during the pre-Roman Iron Age and the High Medieval period, Fagus and Abies remained the main trees of the mountain forest. Due to human promotion, Quercus petraea, which before had nearly disappeared, became the third-most important tree during the Late Medieval period. In the early Modern period, the forest became systematically over-exploited and to a greater part destroyed, and Quercus and later Abies became seldom or even disappeared. According to the pollen record, Picea abies was not present in the area before the Medieval period, but took advantage of the forest devastation of the early Modern period, and was planted preferentially as a forest tree from the $19^{\text {th }}$ century. But it remains unclear whether, in the Schwarzwald National Park without any human impact in the future, the natural forest of Abies and Fagus will come back, because there are still disturbances such as hurricanes and bark-beetle, and overstocking of red deer.
\end{abstract}

\section{Introduction}

The northern Schwarzwald (northern Black Forest) is today one of the most densely-forested landscapes in central Europe. In some parts, particularly in the higheraltitude Grindenschwarzwald, forest cover is more than 90\% (Fischer 1967; Huttenlocher, Dongus 1967). The mountains have a north-south extension of less than $60 \mathrm{~km}$ and a west-east extension of about $40 \mathrm{~km}$, with an altitude up to $1163 \mathrm{~m}$ asl (Hornisgrinde). If one ignores the deep and narrow valleys of Enz, Nagold, Murg and some smaller rivers, mean elevation increases from more than $600 \mathrm{~m}$ asl in the east to more than $1000 \mathrm{~m}$ in the west. The bedrock is mostly Triassic sandstone, but also granite, resulting in rather poor and acidic soils. The climate is sub-oceanic, with decreasing temperatures and increasing precipitation as altitude increases. The Hornisgrinde (1163 m), for example,

*Corresponding author. E-mail: manfred.roesch@rps.bwl.de has an annual mean temperature below $5^{\circ} \mathrm{C}$ and an annual precipitation of $2000 \mathrm{~mm}$.

The Schwarzwald National Park, since $1^{\text {st }}$ January 2014, is situated in the southwestern part of Nordschwarzwald, with elevations over $1000 \mathrm{~m}$. A major aim of the park's management policy is to re-establish a natural forest cover. After an initial phase during which active - though restricted - forest management is allowed, this re-establishment of the natural forest should happen without any human interference. Finally, the potential natural vegetation should cover the entire park (Tüxen 1956; Dierschke 1994). In the actual present-day vegetation, Picea abies, introduced and planted since the $19^{\text {th }}$ century, is the most frequent tree with a coverage of more than $60 \%$. Abies alba and Fagus sylvatica, which are regarded as the main trees of the natural mountain forest in Schwarzwald, are much rarer and cover about the same area as Pinus sylvestris. Other trees, such as Acer pseudoplatanus, Quercus petraea, Alnus glutinosa and incana, Fraxinus excelsior, Tilia platyphyllos, Sorbus aria, Salix caprea, Populus tremula, as well as the introduced 


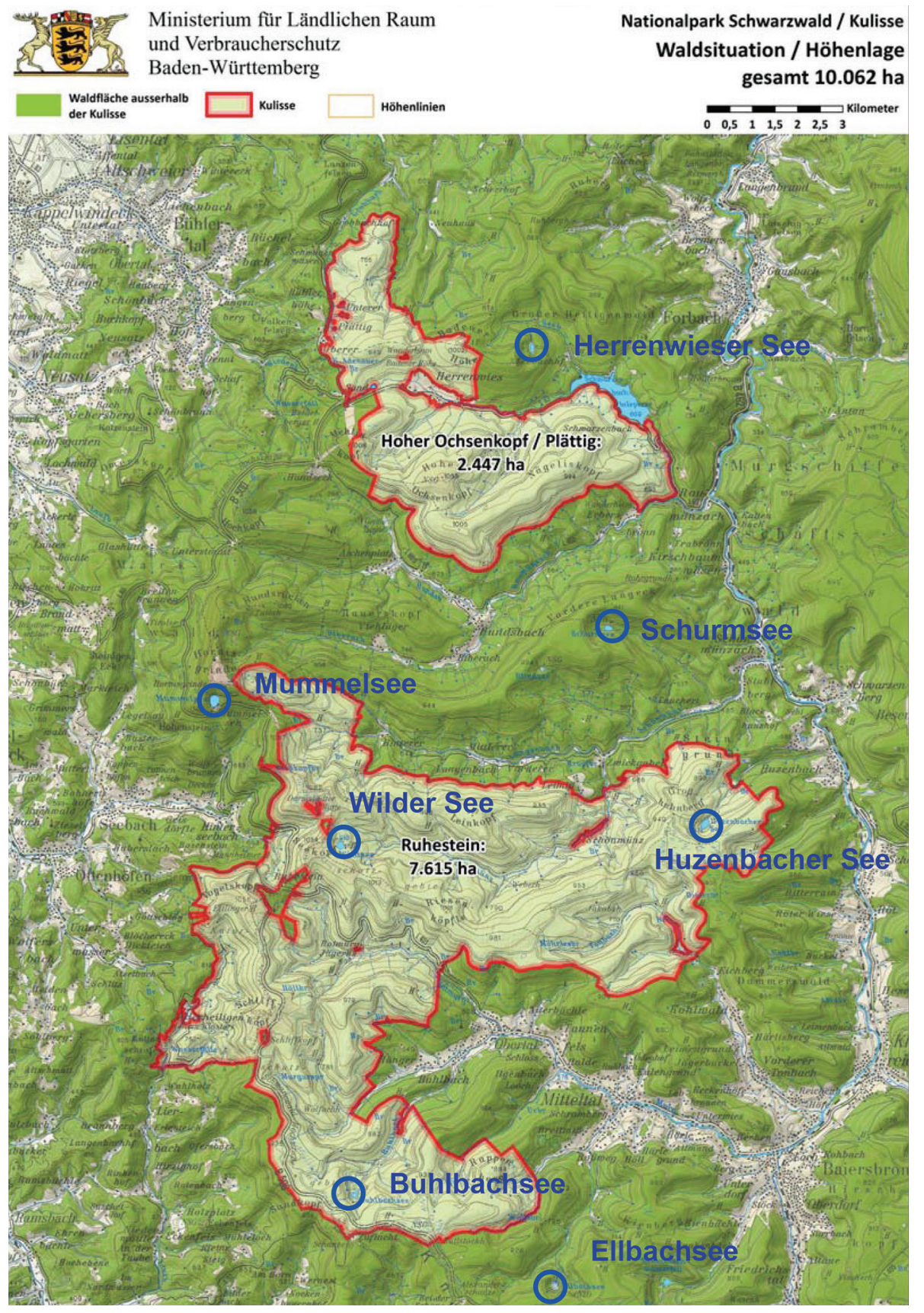

Figure 1. The Schwarzwald National Park and the cirque lakes of Nordschwarzwald. Glaswaldsee is $6 \mathrm{~km}$ to the south of Ellbachsee.

Table 1. The cirque lakes of Nordschwarzwald.

\begin{tabular}{|c|c|c|c|c|c|c|c|c|c|c|c|}
\hline \multirow[t]{2}{*}{ No. } & \multirow[t]{2}{*}{ Lake } & \multirow[t]{2}{*}{ Near } & \multicolumn{2}{|c|}{ Koordinates } & \multirow{2}{*}{$\begin{array}{l}\text { Elev. } \\
\text { m.a.s.l. }\end{array}$} & \multirow{2}{*}{$\begin{array}{c}\text { Length } \\
\text { m }\end{array}$} & \multirow{2}{*}{$\begin{array}{c}\text { Width } \\
\text { m }\end{array}$} & \multirow{2}{*}{$\begin{array}{l}\text { Depth } \\
\text { m }\end{array}$} & \multirow{2}{*}{$\begin{array}{c}\text { Water } \\
\text { expense } \\
\text { ha }\end{array}$} & \multirow{2}{*}{$\begin{array}{c}\text { Pollen } \\
\text { samples }\end{array}$} & \multirow[t]{2}{*}{${ }^{14} \mathrm{C}$ Datings } \\
\hline & & & $\mathbf{N}$ & $\mathbf{E}$ & & & & & & & \\
\hline 1 & Herrenwieser See & $4 \mathrm{~km} \mathrm{w}$ Forbach & $48^{\circ} 40^{\prime} 10^{\prime \prime}$ & $8^{\circ} 17^{\prime} 48^{\prime \prime}$ & 830 & 200 & 80 & 9,5 & 1,2 & 369 & 37 \\
\hline 2 & Glaswaldsee & 4 km e Bad Peterstal & $48^{\circ} 25^{\prime} 36^{\prime \prime}$ & $8^{\circ} 15^{\prime} 45^{\prime \prime}$ & 839 & 200 & 200 & 11 & 2,9 & 153 & 16 \\
\hline 3 & Mummelsee & 4 km ne Seebach & $48^{\circ} 35^{\prime} 56^{\prime \prime}$ & $8^{\circ} 12^{\prime} 07^{\prime \prime}$ & 1028 & 250 & 170 & 17 & 3,3 & 193 & 12 \\
\hline 4 & Schurmsee & $\begin{array}{l}4 \text { km wnw } \\
\text { Schönmünzach }\end{array}$ & $48^{\circ} 36^{\prime} 50^{\prime \prime}$ & $8^{\circ} 19^{\prime} 12^{\prime \prime}$ & 795 & 175 & 105 & 13 & 1,6 & 244 & 19 \\
\hline 5 & $\begin{array}{l}\text { Wilder See am } \\
\text { Ruhestein }\end{array}$ & $4 \mathrm{~km}$ e Seebach & $48^{\circ} 34^{\prime} 15^{\prime \prime}$ & $8^{\circ} 14^{\prime} 24^{\prime \prime}$ & 910 & 170 & 150 & 11,5 & 2,1 & 259 & 16 \\
\hline 6 & Huzenbacher See & 3 km sw Huzenbach & $48^{\circ} 34^{\prime} 33^{\prime \prime}$ & $8^{\circ} 20^{\prime} 58^{\prime \prime}$ & 747 & 250 & 155 & 7,5 & 2,5 & 364 & 22 \\
\hline 7 & Buhlbachsee & 10 km w Baiersbronn & $48^{\circ} 30^{\prime} 06^{\prime \prime}$ & $8^{\circ} 14^{\prime} 43^{\prime \prime}$ & 790 & 200 & 170 & 4,5 & 2,2 & 318 & 18 \\
\hline 8 & Ellbachsee & $4 \mathrm{~km}$ wsw Baiersbronn & $148^{\circ} 29^{\prime} 03^{\prime \prime}$ & $8^{\circ} 18^{\prime} 20^{\prime \prime}$ & 770 & 110 & 90 & 2 & 2,9 & 85 & \\
\hline
\end{tabular}


species Larix decidua and Pseudotsuga menziesii, are rare and of no economic importance.

The big question now is whether Abies will come back as the main component of the area's natural forest - as the forest ecologists hope - or if the system is already too disturbed for a natural resilience.

During the last ice age, the northern Schwarzwald was partly glaciated. The glaciers left behind kettle holes, which, filled with water, became lakes. During the Holocene, most of these so-called cirque lakes developed into mires; only the six largest and deepest, Herrenwieser See, Schurmsee, Mummelsee, Huzenbacher See, Wilder See, and Glaswaldsee, survived as lakes (Table 1, Figure 1). Buhlbachsee and Ellbachsee also have open water surfaces, but artificially caused by dams in early Modern times; their purpose was to flush wood into the valley. All the lakes are rather small, with water surfaces between 1.3 and 3.7 ha.

All lakes are situated at distances of more than two km from lowlands lower than $700 \mathrm{~m}$ asl and are either inside or close to the national park. Thus a pollen analysis of their sediments should be the optimal instrument for getting to know the vegetation history of the national park: a precondition for a prognosis and comprehension of the park's future development. The relationships between the main components of the mountain forest, Abies, Fagus, and Picea, is thereby of particular interest.

Until recent years, the Schwarzwald was believed to have been colonized rather late, more precisely not before the High Medieval period (Hausrath 1938; Brückner 1981; Ottnad 1981; Schaab 2003; Wilmanns 2001; 2009). After the formulation of some doubts, based on palynological and archaeological evidence (Frenzel 1982; Radke 1973; Jensen 1986), mining-archaeological research of the last decade has supported the idea of a much earlier colonization of at least parts of the region (Gassmann et al. 2006). But archaeological evidence is still rare, especially for prehistory. The reasons for this are: the lack of salvage excavations, because there is neither agriculture nor extended building activity; the difficulty of archaeological prospecting due to the topography; and also due to the fact that in the acid soil neither bones nor pottery are preserved.

To get a better understanding of the land-use history of this region, differentiated in space and time, the Laboratory for Archaeobotany of the Regional Heritage Institute BadenWürttemberg, with financial support of the DFG, initiated a fresh vegetation historical project, dealing first with peat profiles from the mires Bruckmisse and Wildseemoor, and later with lake sediments from the centres of the abovementioned cirque lakes (Rösch 2009a; 2009b; 2009/10; 2012; Rösch et al. 2005; 2009, Rösch, Tserendorj 2011a; $2011 b)$. This paper deals with the results of this project. It tries to answer the questions: how was the vegetation and particularly the forest in this region composed, before human impact changed the situation? Can this early natural state be regarded as a model for the potential natural vegetation? And can this natural state be attained, without management, under the given general setup?

\section{Material and methods}

Pollen analysis is the most used and approved method in vegetation history (Berglund 1986). Its direct results are the relative or absolute contents of pollen types in sediments and these are proxy data for forest cover and composition.

To come from pollen percentages to vegetation, these proxy data must be calibrated. Calibration methods have been developed, for example, by Andersen (1970) and by Sugita $(2007 a ; 2007 b)$. They consider the differences in pollen production and dispersion of different species. But these methods cannot answer the question about the point of origin of a single pollen grain. This also influences the question of where does the pollen deposited in a lake or mire come from (Tauber 1965). As a general rule we can assume that with increasing distance between the point of origin and the point of deposition the amount of pollen decreases exponentially. The correlation between vegetation and pollen spectra is not constant, but must be evaluated for every region specifically. Unfortunately a transfer into the past is in principal impossible, but there is agreement that small lakes generally reflect the vegetation in a radius of 1-2 km (Sugita 1994; 2007b).

Most of a plant's pollen remains with the plant and in its direct vicinity. Some pollen, especially of wind-pollinated plants, can reach the upper atmosphere with the help of updrafts. The speed of fall in air of pollen is low compared to typical wind velocities; hence some pollen can be transported rather far. Close to the ground, tall vegetation, and particularly forest, filters much of the pollen from the air, before it can be deposited on the surface of a lake or mire. Therefore a small lake or mire whose surroundings are densely forested has less influx of far-distance pollen than a large basin in an open landscape. We can assume that most of the pollen deposited in the small, forest-surrounded, Schwarzwald lakes originated from distances of perhaps 1-2 km. The pollen component transported from further away should not exceed $10 \%$ (see below). In a flat or hilly landscape, a pollen input from several $\mathrm{km}$ would not be problematic, because in such landscapes the same vegetation units cover huge areas and vegetation gradients are shallow. In mountains, a horizontal distance of a few $\mathrm{km}$ can involve a vertical gradient of several hundreds of meters and therefore sharp changes in vegetation. The horizontal component of the transported pollen flux may be the same as in the flat landscape area, but it is not possible to resolve from which altitudinal belt the pollen has originated. The fact that not all pollen types behave in the same way does not make the problem any easier. We can assume that the pollen of windpollinated trees, as for example Pinus, is capable of being transported rather far, but pollen of wind-pollinated NAP (Non-arboreal pollen), for example Poaceae, only in those cases when they grow in open vegetation. Pollen of forest grasses has only a very slight chance of escaping the forest and travelling very far. Even such grasses of forest-recovery stages as Festuca, Deschampsia, Calamagrostis, Agrostis and others, which are components of the natural forest, are 
hardly reflected in the pollen spectrum outside of the forest: because their pollen has hardly a chance of leaving the small clearings and reaching the atmosphere (Tauber 1965). In the natural forest, after the early Holocene reforestation, the NAP percentages in lake sediments are therefore in most cases clearly below 5\%. Zoogamous plants have a much lower pollen production than wind-pollinated plants. There transport distance depends on the cruising radius of the animal in question. Hexapods, for example the honey bee, can cover several meters up to a few kilometres. Birds can carry pollen in their intestines or in there plumages much farther.

Another problem, already discussed by Firbas (1949), is how to interpret pollen percentages below 1. Generally, vegetation history can prove the presence of a species, but not its absence (recently Ammann et al. 2013). The practical approach is the assumption that a species which is neither documented by pollen nor by other evidence, most probably did not occur. If an anemophilous tree with a rather high pollen production such as Picea should have less than $1 \%$, then the pragmatic point of view would explain these few pollen grains as being transported long-distance, and conclude that Picea is not present in the immediate area. A plausible conclusion maybe, but one that can only be verified by studies comparing actual vegetation and pollen precipitation (cf. Pidek et. al. 2013). But we can assume, with very high certainty, that the species was at least very rare. This discussion is important because we want to know if the pollen influx into the high-altitude Schwarzwald lakes reflect local events, or events, that took place at some distance away and at much lower elevations.
To estimate the amount of long-distance transported pollen in the recent pollen spectrum, the registered pollen and spore types were classified into four classes "local AP", "local NAP", "long-distance AP", and "long-distance NAP" (Table 2, Figure 2). The criteria for the classification were our own vegetation observations and the upper-altitude limits for plant species in the Schwarzwald in Oberdorfer (1970).

All cirque lakes were sampled using a modified Livingstone sampler with a tube length of $1 \mathrm{~m}$ and a tube diameter of $5 \mathrm{~cm}$ (Merkt, Streif 1970). The cores were taken in the centres of lakes at maximum water depth, using a platform. All sediments from the water/sediment-limit down to the Late Weichselian clay were taken. Each profile was dated with about 20 radiocarbon dates to enable reliable time models and the construction of time-linear pollen diagrams. A test to compare the ages of bulk and plant macrofossil data yielded no significant differences, because limestone is lacking in the region. Therefore we could use bulk data.

All profiles were investigated with sampling intervals between 5 and $10 \mathrm{~cm}$ below the first occurrence of Abies and Fagus, and above to the top of the core in $1 \mathrm{~cm}$-intervals without gaps. The pollen sum in each sample was at least 1000 arboreal pollen. Loss-on-ignition was determined using the same sampling concept.

To evaluate the actual pollen spectra at each lake, samples from mosses from their shores were used. The aim was to evaluate the relation between recent vegetation and pollen spectra, to detect long-distance transported pollen, and to have a time control for the upper ends of cores. All data were processed using the programs Tilia and Taxus. For

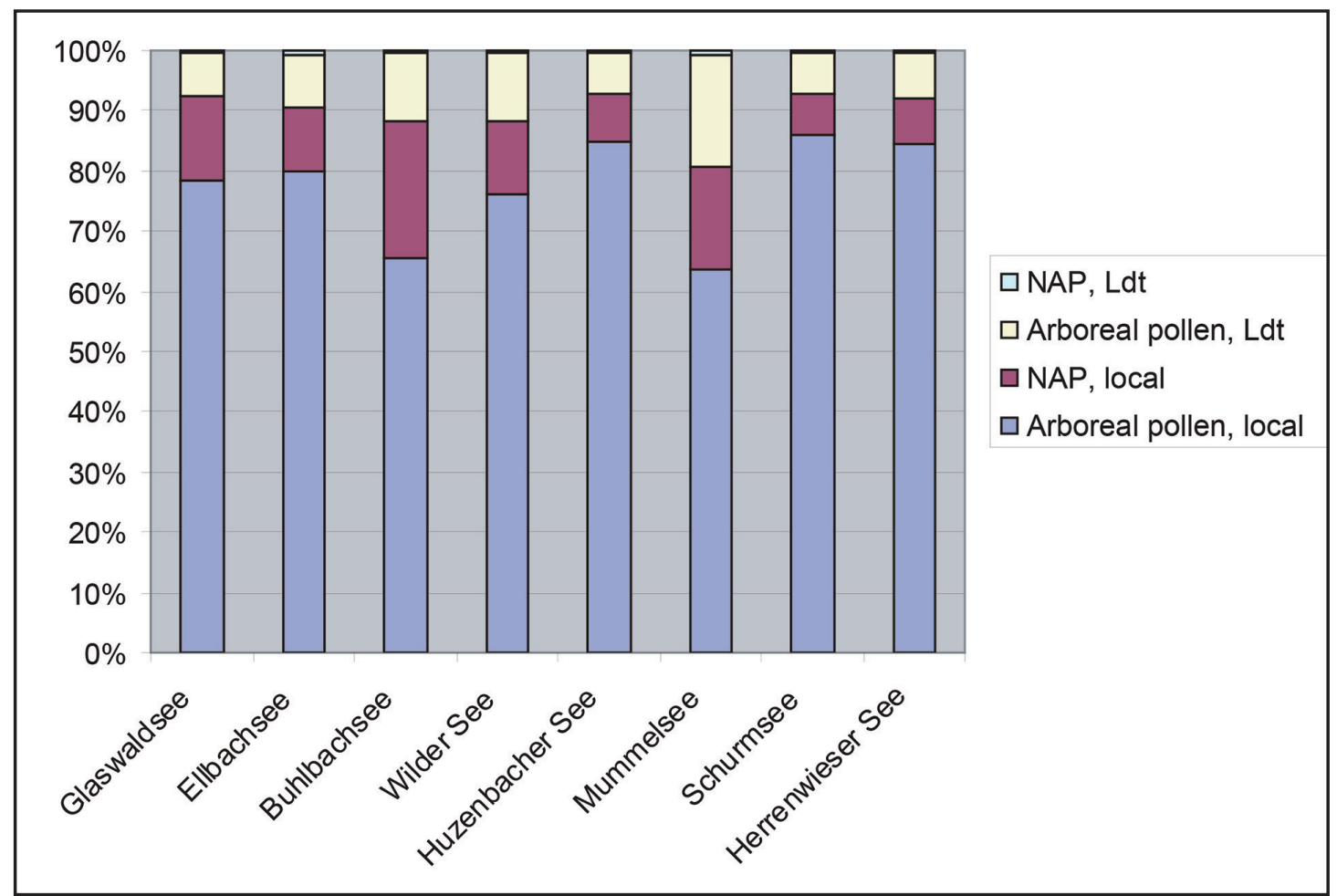

Figure 2. Composition of the recent pollen spectra at Nordschwarzwald lakes, classified into local and long-distance transported arboreal and non-arboral pollen; NAP $=$ Non-arboreal pollen, Ltd $=$ Long-distance transported. 
Table 2. Constancies and percentages of pollen types from surfaces samples (mosses) from the shores of the Nordschwarzwald cirque lakes. Evaluation (column 2): 1 local arboreals 2 extralocal arboreals 3 local non-arboreals 4 extralocal non-arboreals 5 water and mire plants 6 spores; arrangement in groups 1-4 according to upper limit in Schwarzwald after Oberdorfer (2001).

\begin{tabular}{|c|c|c|c|c|c|c|}
\hline \multirow{2}{*}{$\begin{array}{l}\text { Highest occurrence } \\
\text { Schwarzwald m a.s.l. }\end{array}$} & \multirow{2}{*}{ Group } & & \multicolumn{2}{|c|}{ Constancy } & \multicolumn{2}{|c|}{ Frequency } \\
\hline & & & $\mathbf{n}$ & $\%$ & $\mathrm{n}$ & $\%$ \\
\hline 1480 & 1 & Abies alba & 24 & 100 & 1448 & 4,707 \\
\hline \multirow[t]{2}{*}{1450} & 1 & Acer & 18 & 75 & 48 & 0,156 \\
\hline & 3 & Achillea T & 2 & 8 & 2 & 0,007 \\
\hline \multirow[t]{3}{*}{$1100 / 1350$} & 3 & Aconitum T & 1 & 4 & 1 & 0,003 \\
\hline & 2 & Aesculus hippocastanum & 1 & 4 & 1 & 0,003 \\
\hline & 3 & Alchemilla $\mathrm{G}$ & 1 & 4 & 1 & 0,003 \\
\hline 1370 & 3 & Allium ursinum $\mathrm{T}$ & 2 & 8 & 2 & 0,007 \\
\hline $1000 / 1100$ & 1 & Alnus glutinosa $\mathrm{T}$ & 24 & 100 & 1153 & 3,748 \\
\hline \multirow[t]{2}{*}{1190} & 3 & Anthriscus sylvestris & 2 & 8 & 3 & 0,010 \\
\hline & 3 & Apiaceae undiff. & 4 & 17 & 5 & 0,016 \\
\hline 1020 & 3 & Artemisia & 20 & 83 & 43 & 0,140 \\
\hline 1350 & 1 & Aruncus T & 1 & 4 & 1 & 0,003 \\
\hline 1000 & 3 & Astragalus T & 1 & 4 & 1 & 0,003 \\
\hline \multirow[t]{2}{*}{1450} & 3 & Athyrium & 14 & 58 & 78 & 0,254 \\
\hline & 4 & Avena $\mathrm{T}$ & 4 & 17 & 5 & 0,016 \\
\hline $1400 / 1280$ & 1 & Betula & 24 & 100 & 2253 & 7,324 \\
\hline \multirow[t]{4}{*}{1350} & 3 & Blechnum spicant & 3 & 13 & 3 & 0,010 \\
\hline & 3 & Brassicaeae & 22 & 92 & 80 & 0,260 \\
\hline & 6 & Bryideae & 3 & 13 & 3 & 0,010 \\
\hline & 2 & Buxus sempervirens & 1 & 4 & 1 & 0,003 \\
\hline 1025 & 5 & Callitriche & 1 & 4 & 1 & 0,003 \\
\hline 1490 & 3 & Calluna vulgaris & 17 & 71 & 131 & 0,426 \\
\hline 1450 & 3 & Caltha $\mathrm{T}$ & 1 & 4 & 1 & 0,003 \\
\hline 970 & 2 & Carpinus betulus & 24 & 100 & 415 & 1,349 \\
\hline 1445 & 3 & Carum carvi & 3 & 13 & 28 & 0,091 \\
\hline 1000 & 2 & Castanea sativa & 22 & 92 & 204 & 0,663 \\
\hline 1400 & 3 & Centaurea jacea $\mathrm{T}$ & 3 & 13 & 3 & 0,010 \\
\hline 1000 & 3 & Centaurium pulchellum $\mathrm{T}$ & 2 & 8 & 2 & 0,007 \\
\hline \multirow[t]{2}{*}{1280} & 3 & Cerastium fontanum $\mathrm{T}$ & 3 & 13 & 3 & 0,010 \\
\hline & 4 & Cerealia $\mathrm{T}$ & 7 & 29 & 8 & 0,026 \\
\hline \multirow[t]{3}{*}{1420} & 3 & Chaerophyllum hirsutum $\mathrm{T}$ & 1 & 4 & 1 & 0,003 \\
\hline & 3 & Chenopodiaceae & 17 & 71 & 37 & 0,120 \\
\hline & 3 & Cichoriaceae & 11 & 46 & 23 & 0,075 \\
\hline 750 & 2 & Cornus sanguinea & 1 & 4 & 1 & 0,003 \\
\hline \multirow[t]{2}{*}{1350} & 2 & Corylus avellana & 24 & 100 & 796 & 2,588 \\
\hline & 2 & Cotynus coggyria & 1 & 4 & 1 & 0,003 \\
\hline \multirow[t]{2}{*}{1020} & 3 & Cuscuta europaea $\mathrm{T}$ & 1 & 4 & 1 & 0,003 \\
\hline & 5 & Cyperaceae undiff & 23 & 96 & 732 & 2,380 \\
\hline 1400 & 1 & Daphne & 2 & 8 & 2 & 0,007 \\
\hline 950 & 3 & Daucus carota & 8 & 33 & 16 & 0,052 \\
\hline 1450 & 3 & Diphasium alpinum $\mathrm{T}$ & 3 & 13 & 5 & 0,016 \\
\hline 1380 & 5 & Drosera & 3 & 13 & 6 & 0,020 \\
\hline 1400 & 3 & Dryopteris dilatata & 12 & 50 & 75 & 0,244 \\
\hline 1400 & 3 & Dryopteris T & 9 & 38 & 10 & 0,033 \\
\hline 1170 & 3 & Echium & 1 & 4 & 1 & 0,003 \\
\hline \multirow[t]{3}{*}{600} & 4 & Eryngium & 1 & 4 & 1 & 0,003 \\
\hline & 3 & Eupatorium cannabinum $\mathrm{T}$ & 6 & 25 & 6 & 0,020 \\
\hline & 3 & Euphorbia & 1 & 4 & 1 & 0,003 \\
\hline 1470 & 1 & Fagus sylvatica & 24 & 100 & 1730 & 5,624 \\
\hline 1050 & 3 & Fallopia & 2 & 8 & 2 & 0,007 \\
\hline
\end{tabular}


Table 2. Constancies and percentages of pollen types from surfaces samples (mosses) from the shores of the Nordschwarzwald cirque lakes. Evaluation (column 2): 1 local arboreals 2 extralocal arboreals 3 local non-arboreals 4 extralocal non-arboreals 5 water and mire plants 6 spores; arrangement in groups 1-4 according to upper limit in Schwarzwald after Oberdorfer (2001). (Continuation).

\begin{tabular}{|c|c|c|c|c|c|c|}
\hline \multirow{2}{*}{$\begin{array}{l}\text { Highest occurrence } \\
\text { Schwarzwald } \mathrm{m} \text { a.s.l. }\end{array}$} & \multirow{2}{*}{ Group } & & \multicolumn{2}{|c|}{ Constancy } & \multicolumn{2}{|c|}{ Frequency } \\
\hline & & & $\mathbf{n}$ & $\%$ & $\mathbf{n}$ & $\%$ \\
\hline 1420 & 3 & Filipendula & 18 & 75 & 61 & 0,198 \\
\hline 1000 & 1 & Frangula alnus & 1 & 4 & 1 & 0,003 \\
\hline \multirow[t]{2}{*}{1230} & 1 & Fraxinus excelsior & 24 & 100 & 274 & 0,891 \\
\hline & 3 & Geum T & 3 & 13 & 4 & 0,013 \\
\hline 1350 & 3 & Heracleum sphondyleum & 2 & 8 & 3 & 0,010 \\
\hline \multirow[t]{2}{*}{595} & 2 & Hippophaë rhamnoides & 2 & 8 & 2 & 0,007 \\
\hline & 4 & Hordeum T & 13 & 54 & 22 & 0,072 \\
\hline 730 & 2 & Humulus/Cannabis & 11 & 46 & 21 & 0,068 \\
\hline 1425 & 3 & Huperzia selago & 1 & 4 & 1 & 0,003 \\
\hline 1300 & 3 & Hypericum perforatum $\mathrm{T}$ & 2 & 8 & 2 & 0,007 \\
\hline 1100 & 1 & Ilex aquifolium & 2 & 8 & 2 & 0,007 \\
\hline \multirow[t]{2}{*}{1300} & 3 & Impatiens & 1 & 4 & 1 & 0,003 \\
\hline & 6 & indiff & 24 & 100 & 255 & 0,829 \\
\hline 720 & 2 & Juglans regia & 22 & 92 & 70 & 0,228 \\
\hline \multirow[t]{2}{*}{1240} & 1 & Juniperus communis & 4 & 17 & 5 & 0,016 \\
\hline & 1 & Larix decidua $\mathrm{T}$ & 22 & 92 & 68 & 0,221 \\
\hline 1490 & 3 & Lotus & 1 & 4 & 1 & 0,003 \\
\hline 1370 & 3 & Lycopodium clavatum $\mathrm{T}$ & 3 & 13 & 11 & 0,036 \\
\hline 1350 & 3 & Lysimachia vulgaris $\mathrm{T}$ & 2 & 8 & 2 & 0,007 \\
\hline 1470 & 3 & Melampyrum & 5 & 21 & 7 & 0,023 \\
\hline 1100 & 5 & Menyanthes trifoliata & 6 & 25 & 6 & 0,020 \\
\hline 600 & 4 & Mercurialis annua & 4 & 17 & 5 & 0,016 \\
\hline 1200 & 3 & Mercurialis perennis $\mathrm{T}$ & 3 & 13 & 3 & 0,010 \\
\hline \multirow[t]{2}{*}{675} & 4 & Myriophyllum spicatum & 1 & 4 & 1 & 0,003 \\
\hline & 2 & Olea europaea & 5 & 21 & 6 & 0,020 \\
\hline 720 & 4 & Orlaya grandiflora & 1 & 4 & 1 & 0,003 \\
\hline 1400 & 3 & Oxalis acetosella & 3 & 13 & 5 & 0,016 \\
\hline \multirow[t]{2}{*}{1350} & 3 & Pedicularis palustris $\mathrm{T}$ & 1 & 4 & 1 & 0,003 \\
\hline & 3 & Peucedanum palustre $\mathrm{T}$ & 1 & 4 & 1 & 0,003 \\
\hline 1480 & 1 & Picea abies & 24 & 100 & 6396 & 20,793 \\
\hline 1300 & 3 & Pimpinella major $\mathrm{T}$ & 3 & 13 & 3 & 0,010 \\
\hline 1150 & 1 & Pinus sylvestris T & 24 & 100 & 7884 & 25,630 \\
\hline 1320 & 3 & Plantago lanceolata & 23 & 96 & 183 & 0,595 \\
\hline 1450 & 3 & Plantago maior & 4 & 17 & 6 & 0,020 \\
\hline \multirow[t]{3}{*}{1040} & 3 & Plantago media & 4 & 17 & 5 & 0,016 \\
\hline & 2 & Platanus orientalis & 11 & 46 & 26 & 0,085 \\
\hline & 3 & Poaceae undiff & 24 & 100 & 2189 & 7,116 \\
\hline 1300 & 3 & Polygonum aviculare $\mathrm{T}$ & 1 & 4 & 1 & 0,003 \\
\hline 1400 & 3 & Polygonum bistorta & 1 & 4 & 1 & 0,003 \\
\hline \multirow[t]{2}{*}{1100} & 3 & Polygonum persicaria $\mathrm{T}$ & 1 & 4 & 1 & 0,003 \\
\hline & 6 & Polypodiaceae undiff & 22 & 92 & 1160 & 3,771 \\
\hline 1300 & 3 & Polypodium vulgare & 1 & 4 & 1 & 0,003 \\
\hline \multirow[t]{2}{*}{1340} & 1 & Populus & 8 & 33 & 17 & 0,055 \\
\hline & 3 & Potentilla T & 10 & 42 & 14 & 0,046 \\
\hline 1200 & 1 & Prunus T & 5 & 21 & 5 & 0,016 \\
\hline 1280 & 3 & Pteridium aquilinum & 5 & 21 & 12 & 0,039 \\
\hline \multirow[t]{4}{*}{1120} & 2 & Quercus & 24 & 100 & 1235 & 4,015 \\
\hline & 3 & Ranunculaceae undiff. & 7 & 29 & 11 & 0,036 \\
\hline & 3 & Ranunculus acris $\mathrm{T}$ & 18 & 75 & 62 & 0,202 \\
\hline & 2 & Rhus G & 1 & 4 & 1 & 0,003 \\
\hline
\end{tabular}


Table 2. Constancies and percentages of pollen types from surfaces samples (mosses) from the shores of the Nordschwarzwald cirque lakes. Evaluation (column 2): 1 local arboreals 2 extralocal arboreals 3 local non-arboreals 4 extralocal non-arboreals 5 water and mire plants 6 spores; arrangement in groups 1-4 according to upper limit in Schwarzwald after Oberdorfer (2001). (Continuation).

\begin{tabular}{|c|c|c|c|c|c|c|}
\hline \multirow{2}{*}{$\begin{array}{c}\text { Highest occurrence } \\
\text { Schwarzwald m a.s.l. }\end{array}$} & \multirow{2}{*}{ Group } & & \multicolumn{2}{|c|}{ Constancy } & \multicolumn{2}{|c|}{ Frequency } \\
\hline & & & $\mathbf{n}$ & $\%$ & n & $\%$ \\
\hline & 2 & Rosa & 1 & 4 & 1 & 0,003 \\
\hline \multirow[t]{2}{*}{1090} & 3 & Rosaceae undiff. & 12 & 50 & 15 & 0,049 \\
\hline & 3 & Rubiaceae & 13 & 54 & 23 & 0,075 \\
\hline 1400 & 1 & Rubus & 12 & 50 & 13 & 0,042 \\
\hline 1050 & 3 & Rumex aquaticus type & 2 & 8 & 2 & 0,007 \\
\hline 1310 & 3 & Rumex obtusifolius T & 1 & 4 & 2 & 0,007 \\
\hline 1200 & 3 & Rumex undiff. & 23 & 96 & 140 & 0,455 \\
\hline 1450 & 1 & Salix & 24 & 100 & 157 & 0,510 \\
\hline 1200 & 1 & Sambucus nigra/racemosa & 22 & 92 & 55 & 0,179 \\
\hline 1400 & 3 & Sanguisorba officinalis & 1 & 4 & 1 & 0,003 \\
\hline \multirow[t]{4}{*}{1350} & 5 & Scheuchzeria palustris & 3 & 13 & 13 & 0,042 \\
\hline & 4 & Secale cereale & 16 & 67 & 37 & 0,120 \\
\hline & 3 & Senecio T & 8 & 33 & 10 & 0,033 \\
\hline & 3 & Silene $\mathrm{T}$ & 2 & 8 & 2 & 0,007 \\
\hline 720 & 4 & Solanum dulcamara & 4 & 17 & 4 & 0,013 \\
\hline 1390 & 1 & Sorbus T & 12 & 50 & 22 & 0,072 \\
\hline 960 & 5 & Sparganium $\mathrm{T}$ & 2 & 8 & 6 & 0,020 \\
\hline 1493 & 5 & Sphagnum & 14 & 58 & 443 & 1,440 \\
\hline 980 & 2 & Taxus baccata & 6 & 25 & 13 & 0,042 \\
\hline 950 & 1 & Tilia & 15 & 63 & 26 & 0,085 \\
\hline 1130 & 3 & Trientalis europaea & 1 & 4 & 1 & 0,003 \\
\hline \multirow[t]{3}{*}{1490} & 3 & Trifolium repens $\mathrm{T}$ & 1 & 4 & 1 & 0,003 \\
\hline & 3 & Trifolium undiff. & 1 & 4 & 1 & 0,003 \\
\hline & 4 & Triticum T & 14 & 58 & 23 & 0,075 \\
\hline 970 & 5 & Typha latifolia $T$ & 4 & 17 & 4 & 0,013 \\
\hline 1380 & 1 & Ulmus & 16 & 67 & 31 & 0,101 \\
\hline 1300 & 3 & Urtica/Parietaria & 16 & 67 & 86 & 0,280 \\
\hline 555 & 4 & Utricularia & 1 & 4 & 2 & 0,007 \\
\hline 1490 & 3 & Vaccinium $\mathrm{T}$ & 18 & 75 & 139 & 0,452 \\
\hline \multirow[t]{3}{*}{1060} & 3 & Valeriana officinalis $\mathrm{T}$ & 1 & 4 & 1 & 0,003 \\
\hline & 3 & Varia & 10 & 42 & 15 & 0,049 \\
\hline & 3 & Veronica & 1 & 4 & 2 & 0,007 \\
\hline 1000 & 1 & Viburnum lantana & 1 & 4 & 1 & 0,003 \\
\hline \multirow[t]{5}{*}{850} & 1 & Viburnum opulus & 4 & 17 & 4 & 0,013 \\
\hline & 3 & Vicia T & 1 & 4 & 3 & 0,010 \\
\hline & 2 & Vitis & 9 & 38 & 11 & 0,036 \\
\hline & 4 & Xanthium spinosum $\mathrm{T}$ & 11 & 46 & 17 & 0,055 \\
\hline & 4 & Zea mays & 4 & 17 & 4 & 0,013 \\
\hline
\end{tabular}

the calculation of percentages, water plants, spores and Cyperaceae were excluded from the pollen sum. All ages mentioned in this paper are calibrated.

\section{Results and discussion}

\subsection{General outline of the Holocene vegetation history of northern Schwarzwald}

The studies of Glaswaldsee, Wilder See, Huzenbacher See, and Herrenwieser See are published (Rösch 2009a; 2009b;
2009/2010; 2012; Rösch, Tserendorj 2011a; 2011b; Rösch et al. 2009). Mummelsee, Schurmsee und Buhlbachsee are the topic of a PhD thesis at Göttingen University by Gegeensuvd Tserendorj. The evaluation of the Ellbachsee profile is in preparation.

All profiles depict the history of vegetation and landscape from the Late Weichselian to Modern times without gaps, and for the Subboreal and Subatlantic with very high time-resolution. Before the increase of Abies alba, the development in all profiles is very uniform in time and space. (Figure 3). Afterwards there are still similarities between the 


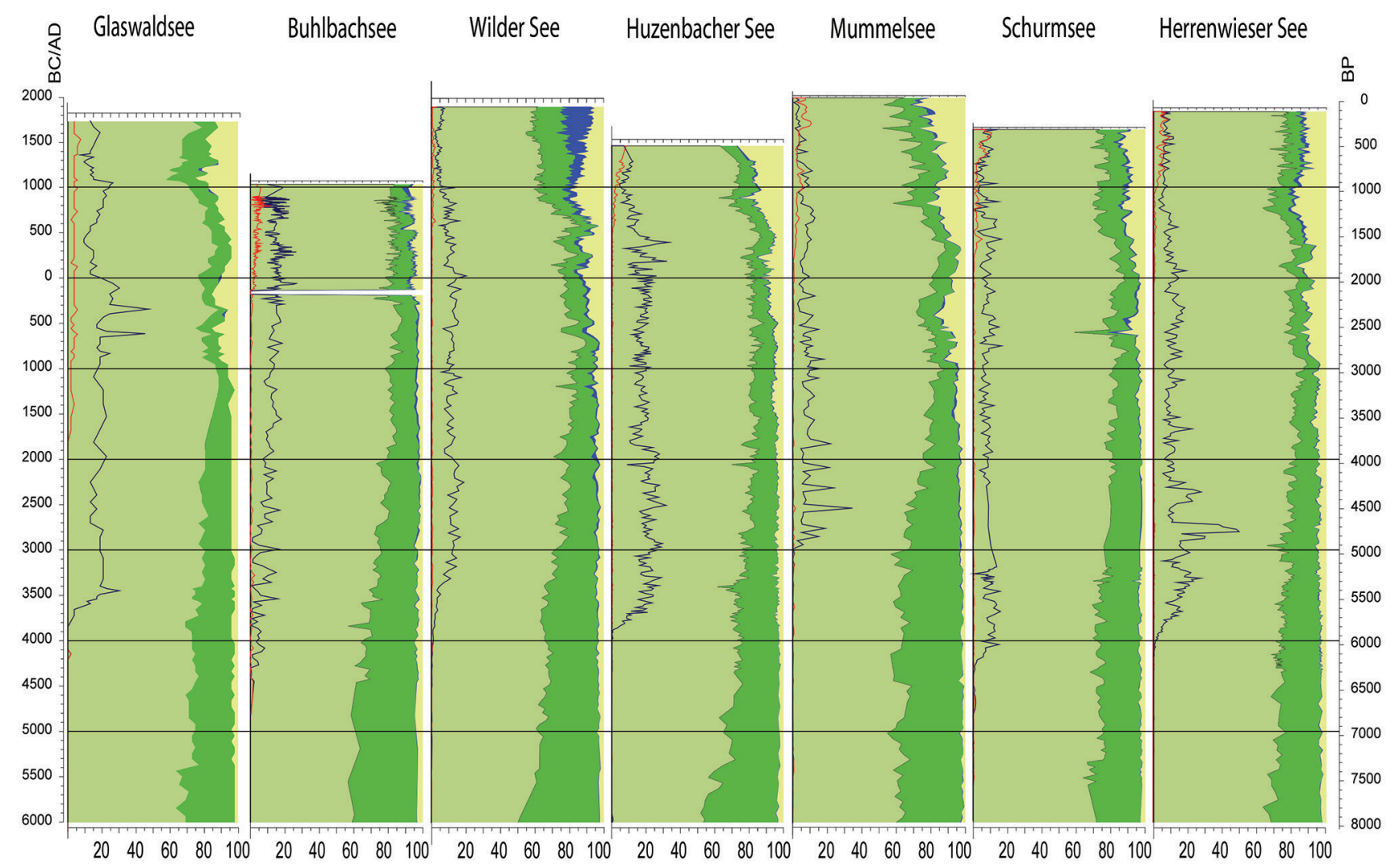

Figure 3. The pollen profiles of the cirque lakes of Nordschwarzwald. Main diagrams: percentages of trees (light green), shrubs (green), dwarf shrubs (blue), and terrestrial NAP (yellow)), adding up to $100 \%$, and the curves of Abies alba (blue line) and Picea abies (red line), linear time axis.

pollen profiles, but differences in detail, concerning timing of events, forest cover and forest composition. Very significant are the differences during prehistory, whereas during the Medieval and Modern Ages the vegetation history is again rather uniform. From these differences we can conclude that the lakes reflect the situation of their surroundings, up to a distance of most probably not more than 1-2 km, without any major input from longer distances; if there had been pollen input originating from the Rhein valley, reflecting human impact in the lowlands, then all the lakes would have shown an identical picture. We can also conclude that the development of the cultural landscape during the Bronze and Iron Age happened at a local scale.

According to the increase of terrestrial NAP (yellow areas in Figure 3) the onset of strong deforestation in the local environs of the lakes had already occurred in the Bronze and pre-Roman Iron Age. This first strong deforestation phase is separated from the Medieval deforestation by a reforestation phase of the Migration and Early Medieval period. The extent and age of these early deforestation phases are different, as well as the percentages of Abies alba (blue lines in Figure 3). These differences between the lakes are evidence for the events being local. As already pointed out, the archaeological evidence is weak, but there is proof for extensive mining activities in the North Schwarzwald during the pre-Roman Iron Age (Gassmann et al. 2006). In the profiles, Buhlbachsee, Wilder See and
Mummelsee, situated near the steep western slopes, as well as at Schurmsee, Abies alba was less frequent. Most frequent was Abies alba at Glaswaldsee in the south, at Huzenbacher See, situated farthest to the east, and at Herrenwieser See, the northernmost lake. But at all lakes, it is, together with Fagus sylvatica, the most frequent tree of the mountain forest, from its first increase until the Late Medieval period. During this time - about five millennia - the pollen curves of Picea abies remain low, hardly exceeding 1\% (red lines in Figure 3).

We can in summary say that the natural forest in northern Schwarzwald was a forest without Picea abies but dominated by Abies alba. However, this natural state had already ceased about 3000 BC due to increasing human impact. Afterwards, Fagus sylvatica became as or even more frequent as Abies alba, but Picea abies was still absent.

\subsection{Vegetation changes of the last five millennia according to the pollen record of Herrenwieser See}

The main trends are visible in all profiles, but Herrenwieser See is a representative pollen profile for Nordschwarzwald, because out of all the lakes it has the longest lithostratigraphy and therefore the best time resolution (Figure 4; Rösch 2012).

Abies alba appears at Herrenwieser See shortly after 5000 BC, shortly after Picea abies and at the same time as Fagus sylvatica (start of continuous pollen curves). Until $4000 \mathrm{BC}$, the percentages of all 3 taxa remain below $1 \%$. From $4000 \mathrm{BC}$, together with the mid-Holocene Ulmus 


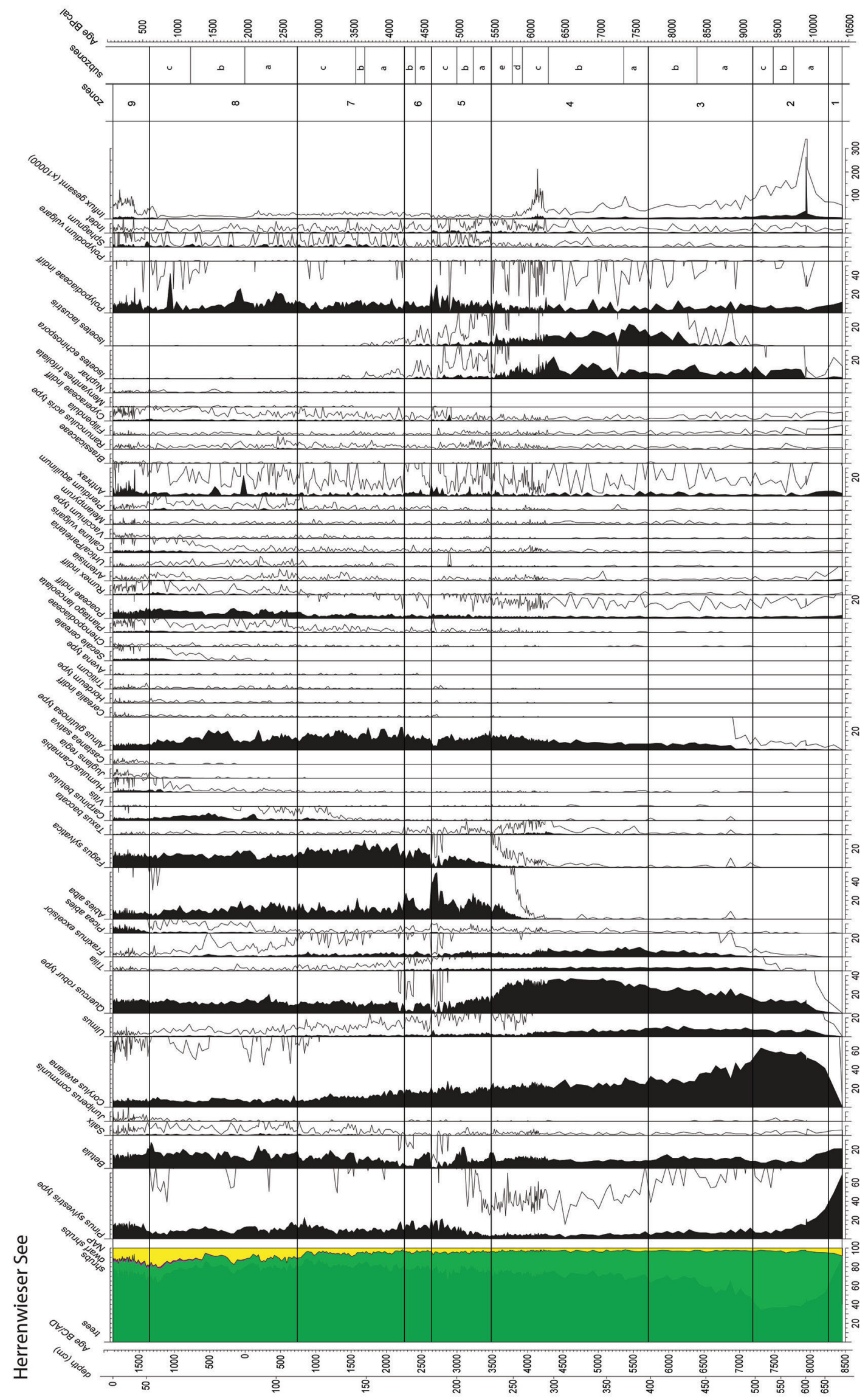

Figure 4. Pollen diagram of Herrenwieser See, linear time axis. 


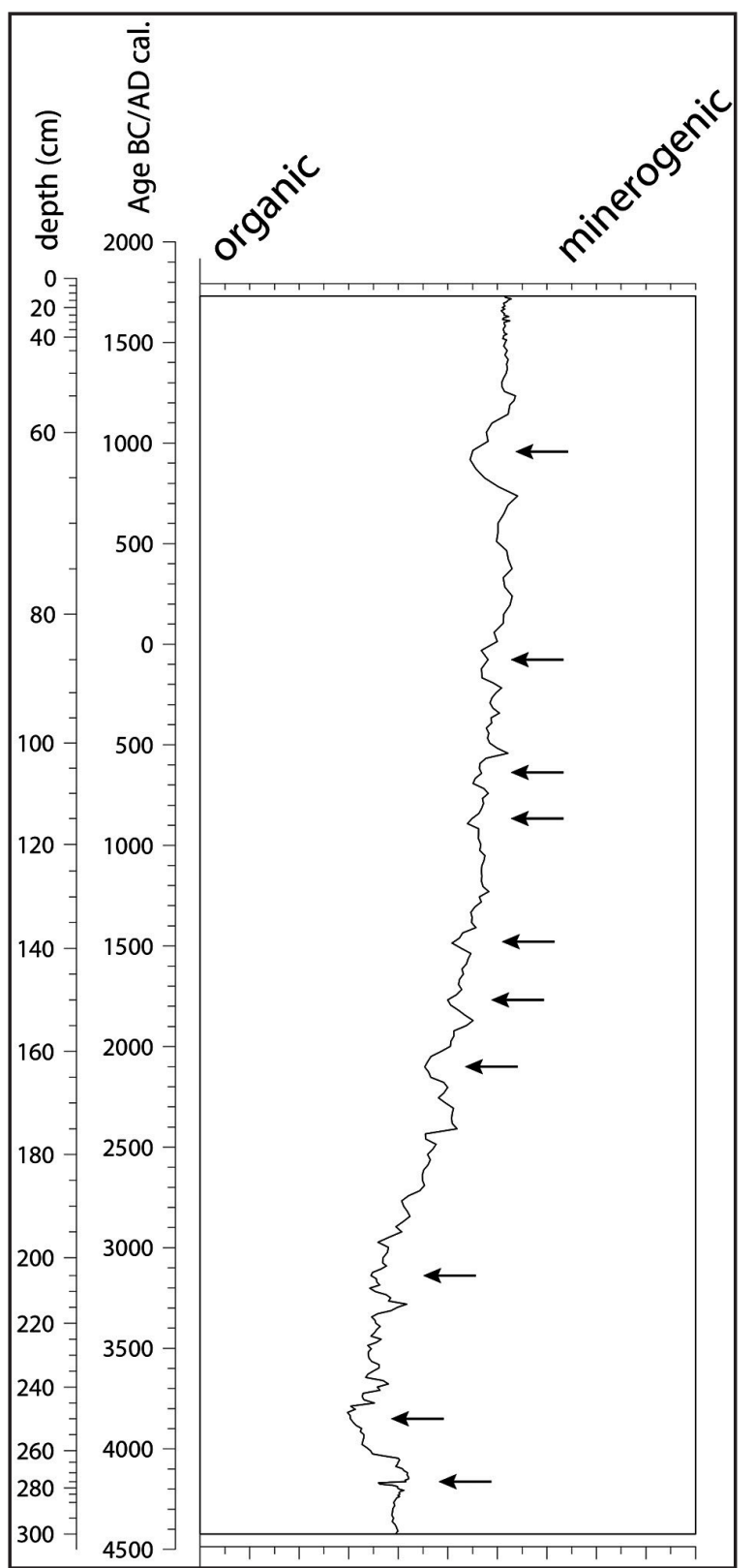

Figure 5. Loss-on-ignition (LOI) curve of Herrenwieser See, linear time axis; arrows indicate erosion phases.

decline (Peglar, Birks 1993), Abies increases and reaches around $3300 \mathrm{BC} 27.5 \%$. After a decline to minimal 5.5\%, accompanied by a Betula peak, Abies increases again and obtains around $2800 \mathrm{BC}$ its maximum value of almost $50 \%$. Only 100 years later, Abies decreases again to less than 9\%. At the same time Betula, Quercus and Fagus sylvatica increase. Afterwards, Abies recovers and obtains, about 2400 $\mathrm{BC}$, once again $28 \%$. These fluctuations of the Abies curve are no spurious effect of calculation, because the total pollen influx is more or less constant during the period considered. Therefore a decrease of the Abies curve from 27 to $9 \%$ indicates a real decline in the Abies pollen influx.

The following fluctuations of the Abies curve are slightly less. Until $700 \mathrm{BC}$ it has between 10 and $15 \%$ and afterwards until 300 BC between 15 and 20\%; afterwards, until the Late
Medieval, it has about $12 \%$. During the Late Medieval and Modern Ages the values of Abies are mostly considerably below $10 \%$.

The prehistoric declines of Abies are accompanied by single cereal grains (particularly around 2700 and 2300 BC), by an increase of apophytes like Plantago lanceolata (particularly 2600-2300 BC), and of charred particles (Figure 4, around 2700 and $2400 \mathrm{BC}$ ) and followed by Betula peaks. There is also a decrease of LOI (Figure 5) caused by minerogenic material from eroded topsoils in the catchment area. In general the LOI of Herrenwieser See gradually increases between $4500 \mathrm{BC}$ and the $18^{\text {th }}$ century $\mathrm{AD}$ from 40 to $60 \%$, a consequence of mire development and raw humus accumulation (Rydberg et al., in print). Sudden and short decreases of LOI against this general trend at 3200, 2300-2000, 1800, 1400, 800, 600 and $200 \mathrm{BC}$, and after 800 $\mathrm{AD}$ indicate soil erosion.

The decreases of Abies are short-term events, taking place over a few decades. Natural causes like forest fires or windstorms are rather improbable. The recovery phases take somewhat longer - over one or two centuries; they may indicate a natural forest succession after the disturbance has ceased. However, other reasons cannot be totally ruled outneither can human impact.

The four decreases of Abies date to $3500 \mathrm{BC}, 3000 \mathrm{BC}$, $2500 \mathrm{BC}$ and $2200 \mathrm{BC}$ and correspond to land-use phases described by Rösch (2012). In contrast to the Bronze Age or younger land use, Neolithic land use is not correlated with a clear increase of NAP, because the Neolithic land-use systems did not result in permanent open vegetation with a lot of wind-pollinated grasses and herbs (Kuneš et al. 2015; Kalis et al. 2003; Rösch 1987).

The first Abies decline dates towards the end of the Younger Neolithic (Michelsberg culture), the second and third into the Final Neolithic (Corded ware culture), the last into the Earliest Bronze Age - more precisely into the time of the Bell Beaker culture (Lüning 1996). So an important forest change from Abies to Fagus, in some phases to pioneer or coppiced forest or even Quercus, happened not in the Medieval period, and not in the pre-Roman Iron Age, but already in the final two millennia of the Neolithic. It should also be mentioned here: the increase of the Pinus curve during the first Abies decline, most probably indicating occupation of the lake shores by Pinus; the decrease of Isoetes lacustris and I. echinospora, starting together with the Abies expansion; and the increase of Sphagnum and Calluna vulgaris, indicating paludification and a shift of the lakes' status from oligotrophic to dystrophic. There is no evidence of soil acidification to hamper the growth of Abies. All decreases of Abies, the prehistoric as well as the later ones, are also phases of LOI decrease, therefore phases of soil erosion (Figure 5). Why Abies became so frequent before Fagus, why it decreased afterwards and lost its leading role to Fagus, and how it could still remain frequent till modern ages, needs further discussion. And, as already pointed out, clear archaeological evidence for pre-Iron age human occupation of the Schwarzwald is very scarce ( $c f$. Valde-Novak, Kienlin 2002). From the Bronze Age onwards, human impact is 


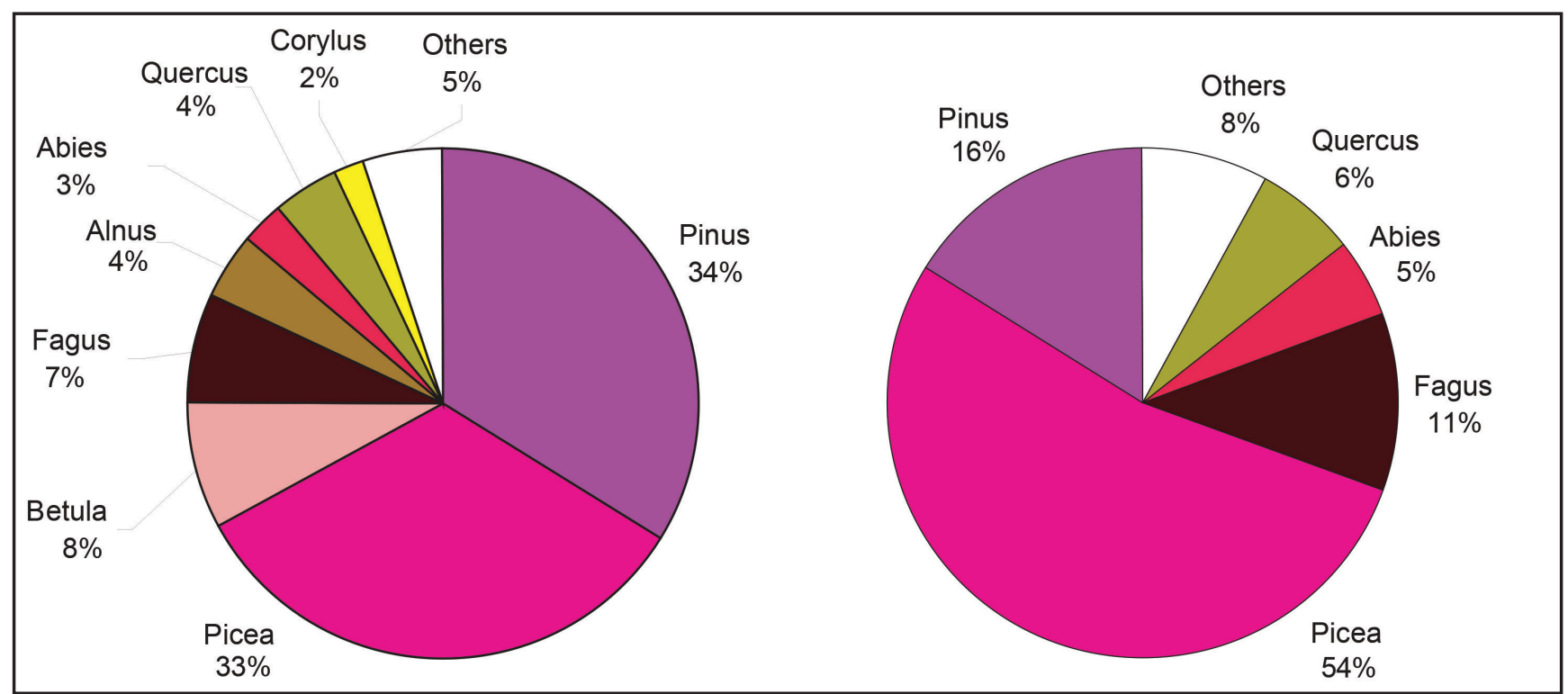

Figure 6. Pollen spectra of mosses from the shore of Herrenwieser See. a) Percentages of arboreal pollen; b) Percentages of arboreal pollen, arboreals from the lake shores excluded.

more clearly visible in the pollen record by an increase of non-arboreals, indicating different forms of land use with permanent open land (Kalis et al. 2013; Rösch et al. 2014).

In comparison with Abies, Fagus increases very slowly. Not until 3000 BC, during the first Abies decline, does Fagus exceed 10\%. After the third Abies decline at 2200 BC, Fagus became the most common tree for a long time. During the pre-Roman Iron Age, Abies again became more frequent than Fagus. But not always increasing Fagus is correlated with decreasing Abies, and vice versa. Other trees, Betula, Pinus, Alnus, are also components of the forest ecosystem and influence, with changing pollen input, the curves of the other trees. These trees can grow within the forest as well as at the lake shore.

During the period being considered, Picea abies has always less than $1 \%$. It does not achieve $1 \%$ until the Roman period. Not until the last decades of the Late Medieval period does its curve slowly exceed $1 \%$. It climbs to $5 \%$ in the early Modern period, at Glaswaldsee, Buhlbachsee and Huzenbacher See somewhat earlier. In the topmost sediments of the long core of Herrenwieser See, dating to the late $17^{\text {th }}$ or early $18^{\text {th }}$ century AD. it always remains below $10 \%$. At the top of the two short cores of Herrenwieser See, dating into the $19^{\text {th }}$ century AD, Picea increases to $20 \%$ (Rösch 2012).

Figure 7. Actual forest composition around Herrenwieser See. Data of Forsteinrichtung, Landesforstverwaltung Baden-Württemberg.

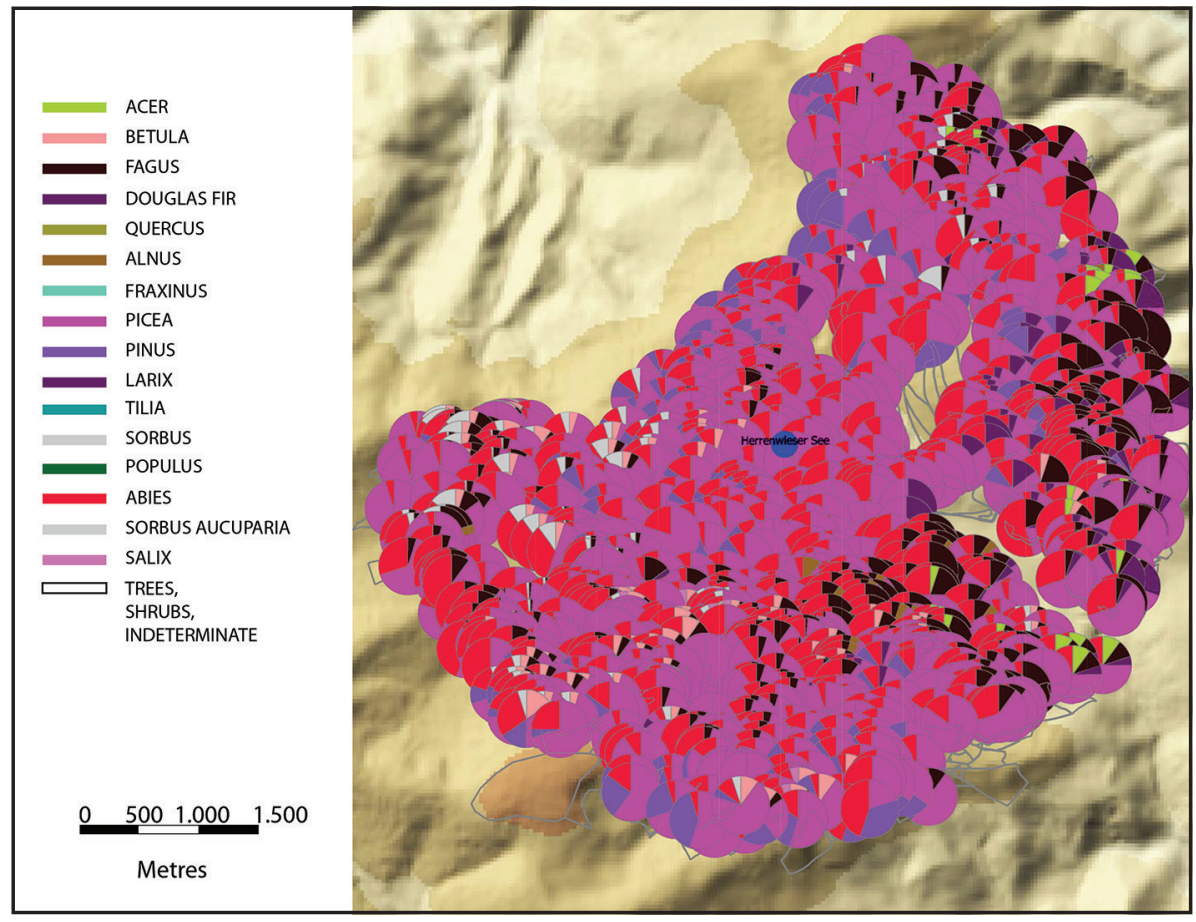


In the actual pollen spectra, preserved in mosses from the shore of Herrenwieser See, Picea has 33\%, about as much as Pinus, Fagus 7\%, and Abies only 3\% (Figure 6a). With Betula, Corylus, Alnus and two thirds of the Pinus as local components of the lake shores excluded from the pollen sum, Picea has 54\%, Pinus 16\%, Fagus 11\%, Abies 5\%, Quercus $6 \%$ and other trees $8 \%$ (Figure $6 \mathrm{~b}$ ). This is in good agreement with the recent forest cover of $60 \%$ Picea, $15 \%$ Abies, 10\% Pinus, 5\% Fagus and 10\% other trees, especially when we keep in mind that this comparison was done without considering the differences in pollen production and distribution (Figure 7). Even in the short core from Herrenwieser See, Picea remains below 20\%, indicating a gap of at least the last several decades. The situation at the other lakes is very similar: The present dominance of Picea is well reflected in the pollen rain.

\subsection{The ecological conditions triggering the forest composition}

In the third millennium BC the expansion of Abies in Schwarzwald was complete. Abies was now the most frequent tree with $40 \%$ or more in the pollen spectrum and most probably an even stronger participation in the forest composition. Compared with Fagus and Picea, and even more so compared with Pinus and Betula, Abies is badly represented in the pollen spectrum (Andersen 1970).

This phase of the vegetation history in Schwarzwald was appropriately called "Tannenzeit" (Lang 1955). It represents the final stage of the natural forest development of the Holocene, triggered only by natural causes - climate, soil, plant migration, competition. All later changes took place under human influence. These changes can therefore be regarded, at least partly, as man-made degradation of the forest. Other trees took advantage of the anthropogenic disturbance, at first Fagus. It has similar ecological features and competitive power as Abies. The outstanding competitiveness of Abies in Schwarzwald is based on its maximal size and age, but mainly on its dark shading of other trees and its ability to tolerate shade in its youth (Ellenberg 1996).

As is well known, Picea did not have any significance in Nordschwarzwald until the Modern Ages (Lang 2005). Why Picea, which was present at high elevations in Südschwarzwald at least since the Subboreal, did not occur in the Nordschwarzwald in larger quantities before the Late Medieval period, is unclear. Ludemann (2014) discusses the early natural occurrence of Picea in Nordschwarzwald, but our data do not confirm this opinion and remove any doubt whether Picea did occur in the region during prehistory.

At least its occurrence in the forest on medium or good soils before the Medieval period can be excluded. Single azonal stands at mires, very steep slopes, or at the base of rock fans, protected from the competition of Abies and Fagus, may have been possible.

In the southern and central Schwarzwald, the situation for Picea was perhaps a little more favourable. Here it did occur at elevations above $1000 \mathrm{~m}$ asl, at the habitats mentioned above, already during prehistory (Lang 2005; Rösch 2000).
The somewhat higher and earlier increasing percentages of Picea at Glaswaldsee (Figure 3) confirm that the history of Picea in Schwarzwald must be discussed at the local scale. At medium-elevation habitats, Picea could not take advantage of its earlier immigration, but was later replaced by Abies (Sudhaus 2005).

We can conclude that the natural forest of Nordschwarzwald would be a forest without Picea, dominated by Abies and Fagus. For the Schwarzwald National Park the question then arises: Will such a natural forest without Picea come back by itself, and how much time will this take?

Quercus, today in Schwarzwald very rare, must also be discussed. Before the increase of Abies, the Schwarzwald forest consisted of Quercus petraea, together with Corylus avellana, Fraxinus excelsior, Ulmus, Tilia and Acer (Figure 4). During the period of dominating Abies and Fagus, Quercus has been represented for more than three millennia rather constantly at 10\%. Assuming 5\% Quercus pollen as being transported long-distance (Figure 5), that still leaves 5\% of local occurrence. Most probably Quercus never did disappear totally from Schwarzwald. In contrast, during the Late Medieval period, Quercus became the most frequent pollen type with more than 20\% (Figure 6 in Rösch 2012), a consequence of the medieval forest management which supported Quercus. From the $16^{\text {th }}$ century onwards, Quercus has decreased to her present level of 5\%. The reason is not "the Little Ice Age", but again forest management: During the period Mercantilism held sway in Europe ( $17^{\text {th }}-18^{\text {th }}$ century), the timber stock of Nordschwarzwald was sold to the Netherlands for ship construction (Scheifele 1996). The Duke of Württemberg and the Margrave of Baden needed the sale revenue to finance their budgets. Initially mostly Quercus was exploited, because sailing ships were constructed with more than $90 \%$ oak (Quercus). However, due to its high density, oak could only be rafted in combination with coniferous wood. There is historical evidence from written sources of the occurrence of Quercus up to the highest elevations of Nordschwarzwald (Scheifele, 1996). The time of the "Holländertannen" (Dutch firs) came later, mainly during the $18^{\text {th }}$ century.

When the absolutist sovereigns had finally achieved what many generations of farmers, charcoal burners and miners since the Iron Age had not been able to do - to nearly totally deforest the Nordschwarzwald - Picea came as an emergency measure for the forest administrators. Before the start of large-scale reforestation in the $19^{\text {th }}$ century, Picea was already present in the region from the $16^{\text {th }}$ century; it had already invaded disturbed forests (von Hornstein 1951). Concerning the occurrence of Picea in the Modern Ages, vegetation history and forest history are in good accord (Hausburg 1968).

\subsection{General framework for the future forest development in Schwarzwald National Park}

Under natural conditions, Abies is the strongest competitor among the trees of the mountain forest, at least in Schwarzwald with a suboceanic, wet, and not-too-cold climate. Under 
Figure 8. Young Abies alba damaged by game animals, Nationalpark Schwarzwald.

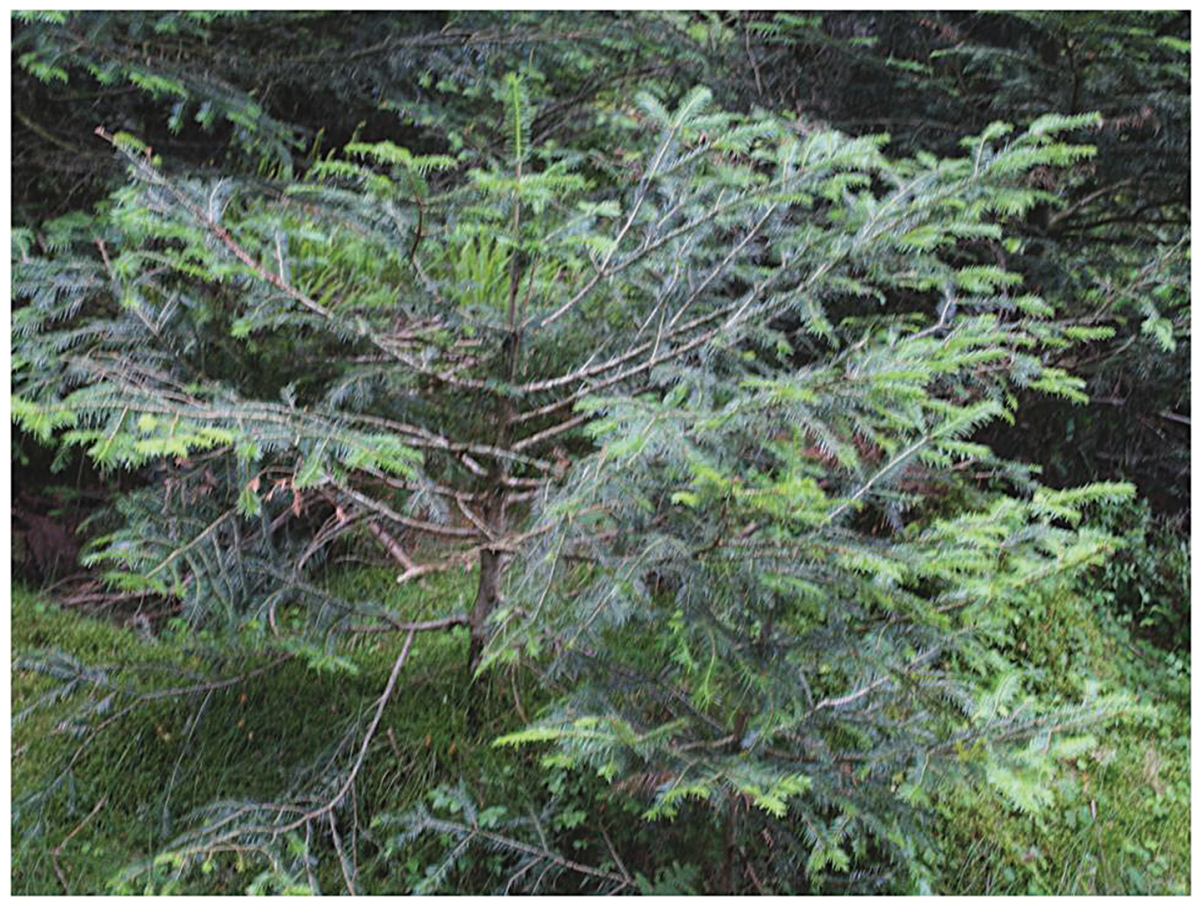

different climatic and soil conditions, the story may be different. On the other hand, it is very sensitive against forest disturbance, especially most forms of human impact. It cannot recover from rootstock, is sensitive against fire, and cannot start as a first colonizer of clearings. Red deer and roe deer feed on young Abies saplings by preference and thus give other species such as Picea or Juniperus an advantage. Just how much damage caused through the browsing of game animals can influence today the future of the forest demonstrates a viewpoint on mixed forests of Abies and Picea that is held within the National Park (Figure 8). Picea seedlings can grow undisturbed, whereas Abies seedlings suffer strong or even lethal damage by game animal browsing.

Of the three most important mountain trees, Picea suffers least from browsing. Furthermore, it can act as a pioneer species in clearings. Thus game animals play a crucial role in the future of the forest (Senn, Suter 2003). Not only in Schwarzwald, but in many other forests in Germany, an attempt at reforestation with deciduous trees or Abies is only possible by fencing off sensitive areas.

Throughout the entire Holocene red deer were present in Schwarzwald, and since the Bronze Age or even earlier there has also been browsing by domestic animals. Nevertheless, Abies remained together with Fagus the main tree in Schwarzwald until the High Medieval period. It was able to cope with this and other human impacts, perhaps even taking advantage from certain ways of forest management that did not include large clearings. Without the competition of Picea, the browsing had no lasting effect. Obviously, the damage on Abies seedlings made by domestic animals was less than that caused by game animals (Málek 1971; 1981). On abandoned clearings, a pioneer forest of Betula gave Abies the chance to come back; perhaps the farmers kept the wild game density low to protect their fields. This situation changed when hunting became a privilege of the nobility and rich. Getting trophies was now more important than preventing the fields from being damaged. The density of wild game was artificially increased substantially to guarantee the hunters more success and more pleasure.

Abies was able to deal with this situation too. But when in the $19^{\text {th }}$ century huge clearings were reforested with Picea, its battle was finally lost. Abies could not be used to reforest the clearings because it is not a pioneer tree growing in open spaces.

Inside the national park there will be no artificially-created clearings in the future, but there will be clearings made by hurricanes and extensive damage by bark beetle. Therefore, there will always be some open land where the forest must start again. It is an open question as to whether, despite the overstocking of red dear, Abies will be able to successfully compete against Picea in this situation. Perhaps this will be the case when the reforestation, as in the past, will be initiated by Betula instead of Picea (Figure 4). To give Abies a better chance, the populations of red and roe deer should be reduced drastically. Because of the national park's small size and its present contact to the surrounding landscape this will be difficult.

The history of Abies in Schwarzwald is not singular. There are, for example, similarities with that of the Bohemian Forest (Svobodova et al. 2001; 2002). In the Southern Alps, Abies had increased and become the most common tree already in the $7^{\text {th }}$ millennium $\mathrm{BC}$, but then nearly disappeared in the $4^{\text {th }}$ and early $3^{\text {rd }}$ millennium BC (Finsinger, Tinner 2006; Gobet et al. 2000; Tinner et al. 1999; van der Knaap et al. 2005). Climatic change, forest fires, and human impact are given as reasons for this change (Wick, Möhl 2006; Rösch et al. 2012). In eastern central Europe, Abies arrived later (Kozáková et al. 2011); here it reached its maximum during the Bronze and Iron Age. It then declined in the pollen record during the High Medieval. 
There are stillopen questions. The existence of different Abies races, each with different eco-physiological characteristics, must also be taken into account (Burga, Hussendörfer 2001). Populations in regions with a warmer climate have perhaps lower shade requirements and higher drought resistance. Within a regional population, the range of eco-physiological behaviour and potential can be wide, allowing the species as a whole to deal with the changing environmental conditions. This would explain why Abies has expanded in the past in regions which are thought by geobotanists and forest scientists to be too warm and dry, for example, into the Hoch- and Oberrhein valley, and why the Late Medieval reforestation in lowland areas by the seeding of conifers, initiated by Peter Stromer in Nürnberg, was not only able to use Pinus sylvestris and Picea abies, but Abies alba as well (Lechner 2005; Wick, oral announcement; Hasel, Schwartz 2002).

\section{Conclusions}

High-resolution and radiocarbon-dated pollen profiles from the central cores of small lakes in Nordschwarzwald have been able to reflect the history of landscape, vegetation and human impact during the last 11 millennia. This paper focuses on the history of the mountain forest and its main tree components and on possible reasons for the changes. The reasons for the shift from mixed oak forest to dominating Abies in the $4^{\text {th }}$ millennium $\mathrm{BC}$ are not clear, but at the same time there occurred a change in the lake ecology and chemistry, indicated by a decrease of Isoetes and by an increase of mercury (Rydberg et al., in press). An acidification of the surrounding soil can be deduced by the increase of Calluna and Ericaceae. In the third millennium BC Abies decreased and Fagus became more frequent. This is accompanied by Betula peaks and some human impact indicators, of which, with good reason, we think, that they are local. From the third millennium BC to the first millennium AD the relation between Abies and Fagus remained rather unchanged. A point to mention is the strong role played by Quercus, having an occurrence even at higher altitudes. Picea was present only during the last millennium and became the most frequent tree when the vastly destroyed forest was reforested preferentially with Picea. Foresters, ecologists and botanists expect, or at least hope, that inside the Schwarzwald National Park, without any future human impact, Abies will regain its dominating role and will replace Picea. The vegetation history, at least of the last millennium, and the continuation of disturbances like windstorms, bark beetle, and the overstocking of game (deer), put some doubt on this expectation.

\section{Acknowledgements}

The palynological investigations in Nordschwarzwald were supported by the DFG. For assistance in the field and laboratory, as well as for discussions, I have to thank Willi Tanner, Karl-Heinz Feger and his team, Harald Biester,
Helmut Volk, Lucia Wick, Jutta Lechterbeck, Elske Fischer, Gegeensuvd Tserendorj, Fabian Rösch, Max Markert, Tanja Märkle, Eva Klimek, Roza Schneider, and Stella Tomasi. Furthermore, I thank Radka Kozaková and an anonymous reviewer for very helpful comments.

\section{References}

AMMANN, B., VAN DER KNAAP, W. O., LANG, G., GAILLARD, M.J., KALTENRIEDER, P., RÖSCH, M., FINSINGER, W., WRIGHT H. E., TINNER, W. 2014: The potential of stomata analysis in conifers to estimate presence of conifer trees: examples from the Alps. Vegetation History and Archaeobotany 23, 249-264.

ANDERSEN, S. T. 1970: The relative pollen productivity and pollen representation of North European trees, and correction factors for tree pollen spectra. Geological Survey of Denmark 2/96, Copenhagen.

BERGLUND, B. E. 1986: Handbook of Holocene Palaeoecology and Palaeohydrology. Chichester.

BRÜCKNER, H. 1981: Die Entwicklung der Wälder des Schwarzwaldes durch die Nutzung vergangener Jahrhunderte und ihre heutige Bedeutung. In: Liehl, E., Sick, W. D. (Eds.): Der Schwarzwald - Beiträge zur Landeskunde. Veröff. Des Alemannischen Instituts Freiburg 47 (Bühl), $155-180$.

BURGA, C. A., HUSSENDÖRFER, E. 2001: Vegetation history of Abies alba Mill. (silver fir) in Switzerland - pollen analytical and genetic surveys related to aspects of vegetation history of Picea abies (L.) H. Karsten (Norway spruce). Vegetation History and Archaeobotany 10, $151-159$.

DIERSCHKE H. 1994: Pflanzensoziologie. Grundlagen und Methoden. Ulmer, Stuttgart.

ELLENBERG, H. 1996: Vegetation Mitteleuropas mit den Alpen. Ulmer, Stuttgart.

FEZER, F. 1957: Eiszeitliche Erscheinungen im nördlichen Schwarzwald. Forsch. Deutsch. Landeskde. 87, Bad Godesberg.

FINSINGER, W., TINNER, W. 2006: Holocene vegetation and landuse changes in response to climatic changes in the forelands of the southwestern Alps, Italy. Journal of Quaternary Science 21, 243-258.

FIRBAS, F. 1949: Spät- und nacheiszeitliche Waldgeschichte Mitteleuropas nördlich der Alpen. Bd.1, Fischer, Jena.

FISCHER, H. 1967: Die naturräumlichen Einheiten auf Blatt 169 Rastatt. Geographische Landesaufnahme 1:200 000, Naturräumliche Gliederung Deutschlands, Bad Godesberg.

FRENZEL, B. 1982: Über eine vormittelalterliche Besiedlung in einigen Teilen des nördlichen Schwarzwaldes. In: Winkel, H. (Ed.): Festschrift für Günther Franz zum 80. Geburtstag, (Thorbecke, Sigmaringen). 239263.

GASSMANN, G., WIELAND, G., RÖSCH, M. 2006: Das Neuenbürger Erzrevier im Nordschwarzwald als Wirtschaftsraum während der Späthallstatt- und Frühlatènezeit. Germania 84/2, 273-306.

GOBET, E., TINNER, W., HUBSCHMID, P., JANSEN, I., WEHRLI, M., AMMANN, B., WICK, L. 2000: Influence of human impact and bedrock differences on the vegetational history of the Insubrian Southern Alps. Vegetation History and Archaeobotany 9, 175-187.

HASEL, K., SCHWARTZ, E. 2002: Forstgeschichte. Ein Grundriss für Studium und Praxis. Kessel, Remagen.

HAUSBURG, H. 1967: Die Ausbreitung der Fichte im HornisgrindeKniebis-Murggebiet des Nordschwarzwaldes bis etwa 1800. Mitt. Ver. Forstliche Standortskde. Forstpflanzenzücht 17, 3-22.

HAUSRATH, H. 1938: Aus der Waldgeschichte des Schwarzwaldes. Freiburger Universitätsreden 26, Freiburg.

V. HORNSTEIN, F. 1951: Wald und Mensch. Waldgeschichte des Alpenvorlandes Deutschlands, Österreichs und der Schweiz. Maier, Ravensburg.

HUTTENLOCHER, F., DONGUS, H. 1967: Die naturräumlichen Einheiten auf Blatt 170 Stuttgart. Geographische Landesaufnahme 1:200 000, Naturräumliche Gliederung Deutschlands, Bad Godesberg.

KALIS, AJ., MERKT, J., WUNDERLICH, J. 2003: Environmental changes during the Holocene climatic optimum in central Europe - human impact 
and natural causes. Quaternary Science Reviews 22, 33-79.

KOZÁKOVÁ, R., ŠAMONIL, P., KUNEŠ, P., NOVÁK, J., KOČÁR, KOČÁROVÁ, R. 2011: Contrasting local and regional Holocene histories of Abies alba in the Czech Republic in relation to human impact. Evidence from forestry, pollen and anthracological data. The Holocene 21, 431-444.

KUNEŠ, P., SVOBODOVÁ-SVITAVSKÁ, H., KOLAR, J., HAJALOVÁ, M., ABRAHAM, V., MACEK, M., TKÁČ, P., SZABO, P. 2015: The origin of grasslands in the temperate forest zone of east-central Europe: long-term legacy of climate and human impact. Quaternary Science Reviews 116, 15-27.

JENSEN, I. 1986: Der Schlossberg von Neuenbürg. Eine Siedlung der Frühlatènezeit im Nordschwarzwald. Materialhefte z. Vor- u. Frühgesch. Bad.-Württ. 8, Theiss, Stuttgart.

LANG, G. 1955: Neue Untersuchungen über die spät- und nacheiszeitliche Vegetationsgeschichte des Schwarzwaldes. II. Das absolute Alter der Tannenzeit im Südschwarzwald. Beitr. naturk. Forsch. Südwestdeutschl. $14,24-31$

LANG, G. 2005: Seen und Moore des Schwarzwaldes als Zeugen spätglazialen und holozänen Vegetationswandels. Andrias 16, Staatliches Museum für Naturkunde, Karlsruhe.

LECHNER, A. 2005: Paläoökologische Beiträge zur Rekonstruktion der holozänen Vegetations-, Moor- und Flussauenentwicklung im Oberrheintiefland. Dissertation zur Erlangung Universität Freiburg, Freiburg.

LUDEMANN, T. 2014: Die Wälder des Nordschwarzwaldes. Standort Wald 48, 41-62.

LÜNING, J. 1996: Erneute Gedanken zur Benennung der neolithischen Perioden. Germania 74, 233-237.

MÁLEK, J. 1971: Vliv pastvy dobytka na přeživáni semenáčků a přirozenou obnuvu jedle (The influence of livestock grazing on the survival of silver fir seedlings and on the natural regeneration of the silver fir). Lesnická práce 50, 543-546.

MÁLEK, J. 1981: Problematik der Ökologie der Tanne (Abies alba Mill.) und ihres Sterbens in der ČSSR. Forstwiss. Central Bl. 100, 170-174.

MERKT, J., STREIF, H. J. 1970: Stechrohr-Bohrgeräte für limnische und marine Lockersedimente. Geologisches Jahrbuch 88, 137-148.

OBERDORFER, E. 1970: Pflanzensoziologische Exkursionsflora für Süddeutschland. Ulmer, Stuttgart.

OTTNAD, B. 1981: Zur Territorialgeschichte des Schwarzwalds. In: Liehl, E., Sick, W. D. (Eds.): Der Schwarzwald - Beiträge zur Landeskunde, Veröff. des Alemannischen Instituts Freiburg 47, 181-204.

PEGLAR, S. M., BIRKS, H. J. B. 1993: The mid-Holocene Ulmus fall at Diss Mere, South-East England - disease and human impact? Vegetation History and Archaeobotany 2, 61-68.

PIDEK, I. A., SVITAVSKÁ-SVOBODOVÁ, H., VAN DER KNAAP, W. O., MAGYARI, E. 2013: Pollen percentage thresholds of Abies alba based on 13-year annual records of pollen deposition in modified Tauber traps: perspectives of application to fossil situations. Review of Palaeobotany and Palynology 195, 26-36.

RADKE, J. 1973: Landschaftsgeschichte und -ökologie des Nordschwarzwaldes. Hohenheimer Arbeiten 68, Stuttgart.

RÖSCH, M. 1987: Zur Umwelt und Wirtschaft des Neolithikums am Bodensee - Botanische Untersuchungen in Bodman-Blissenhalde. Archäol. Nachr. a. Baden 38/39, 42-53.

RÖSCH, M. 2000: Long-term human impact as registered in an upland pollen profile from the southern Schwarzwald, south-western Germany. Vegetation History and Archaeobotany 9, 205-218.

RÖSCH, M. 2009a: Zur vorgeschichtlichen Besiedlung und Landnutzung im nördlichen Schwarzwald aufgrund vegetationsgeschichtlicher Untersuchungen in zwei Karseen. Mitt. Ver. Forstl. Standortskunde $u$. Forstpflanzenzüchtung 46, 69-82.

RÖSCH, M. 2009b: Botanical evidence for prehistoric and medieval land use in the Schwarzwald. In: Medieval Rural Settlement in Marginal Landscapes. Ruralia VII, Turnhout (Belgium), 335-343.

RÖSCH, M. 2009/2010: Der Nordschwarzwald - das Ruhrgebiet der Kelten? Neue Ergebnisse zur Landnutzung seit über 3000 Jahren. Alemannisches Jahrbuch 2009/2010, 155-169.

RÖSCH, M. 2012: Vegetation und Waldnutzung im Nordschwarzwald während sechs Jahrtausenden anhand von Profundalkernen aus dem Herrenwieser See. Standort. Wald, Mitteilungen des Vereins für forstliche
Standortskunde und Forstpflanzenzüchtung 47, 43-64

RÖSCH, M., VOLK, H., WIELAND, G. 2005: Frühe Waldnutzung und das Alter des Naturwaldes im Schwarzwald. AFZ Der Wald 12, 636-638.

RÖSCH, M., GASSMANN, G., WIELAND, G. 2009: Keltische Montanindustrie im Schwarzwald - eine Spurensuche. In: Kelten am Rhein. Proceedings of the Thirteenth International Congress of Celtic Studies, erster Teil, Archäologie, Ethnizität und Romanisierung, Beihefte Bonner Jahrbücher 58,1, 263-278.

RÖSCH, M., TSERENDORJ, G. 2011a: Florengeschichtliche Beobachtungen im Nordschwarzwald (Südwestdeutschland). Hercynia N. F. 44, 53-71.

RÖSCH, M., TSERENDORJ, G. 2011b: Der Nordschwarzwald früher besiedelt als gedacht? Pollenprofile belegen ausgedehnte vorgeschichtliche Besiedlung und Landnutzung. Denkmalpflege in Baden-Württemberg 40, 2, 66-73.

RÖSCH, M., FISCHER, E., LECHTERBECK, J., WICK, L. 2012 : Pollenanalysen an drei Bohrkernen aus dem Profundal des Ortasees (Piemont, Italien). In: Stobbe, A., Tegtmeier, U. (Eds.): Verzweigungen, eine Würdigung für A. J. Kalis und J. Meurers-Balke. Frankfurter Archäologische Schriften 18, 225-247.

RYDBERG J., RÖSCH, M., HEINZ E., BIESTER H. (in print): The influence of catchment vegetation on mercury accumulation in lake sediments from a long-term perspective. Science of the Total Environment.

SCHAAB, M. 2003: Beiträge zur Siedlungs- und Wirtschaftsgeschichte des Schwarzwaldes. Veröff. Komm. Geschichtl. Landeskde. Bad.-Württ., Reihe B, Forschungen, 156, Kohlhammer, Stuttgart.

SCHEIFELE, M. 1996: Als die Wälder auf Reisen gingen. Wald-HolzFlößerei in der Wirtschaftsgeschichte des Enz-Nagold-Gebietes. Braun, Karlsruhe. Company: Braun.

SENN, J., SUTER, W. 2003: Ungulate browsing on silver fir (Abies alba) in the Swiss Alps. Beliefs in search of supporting data. Forest Ecology and Management 181, 151-164.

SUDHAUS, D. 2005: Paläoökologische Untersuchungen zur spätglazialen und holozänen Landschaftsgeschichte des Ostschwarzwaldes im Vergleich mit den Buntsandsteinvogesen. Freiburger Geographische Hefte 64, Freiburg.

SUGITA, S. 1994: Pollen Representation of Vegetation in Quaternary Sediments: Theory and Method in Patchy Vegetation. Ecology 82 (4), 881-897.

SUGITA, S. 2007a: Theory of quantitative reconstruction of vegetation. I. Pollen from large sites REVEALS regional vegetation. The Holocene 17, 229-241.

SUGITA, S. 2007b: Theory of quantitative reconstruction of vegetation. II. All You Need Is LOVE. The Holocene 17, 243-257.

SVOBODOVÁ, H., REILlE, M., GOEURY C. 2001: Past vegetation dynamics of Vltavský luh, upper Vltava river valley in the Šumava mountains, Czech Republic. Vegetation History and Archaeobotany 10/4, 185-199.

SVOBODOVÁ, H., SOUKUPOVÁ, L., REILlE, M. 2002: Diversified development of mountain mires, Bohemian Forest, Central Europe, in the last 13,000 years. Quaternary International 91, 123-135.

TAUBER, H. 1965: Differential pollen deposition and the interpretation of pollen diagrams. Danmarks Geologiske Undersøgelse II/89, 1-69.

TINNER, W., HUBSCHMID, P., WEHRLI, M., AMMANN, B., CONEDERA, M. 1999: Long-term forest fire ecology and dynamics in Southern Switzerland. Journal of Ecology 87, 273-289.

TÜXEN, R. 1956: Die heutige potentielle natürliche Vegetation als Gegenstand der Vegetationskartierung. Angew. Pflanzensoz. 13, 5-42.

VALDE-NOWAK P., KIENLIN, T. L. 2002: Neolithische Transhumanz in den Mittelgebirgen: Ein Survey im westlichen Schwarzwald. Prähistorische Zeitschrift 77, 29-75.

VAN DER KNAAP, W. O., VAN LEEUWEN, J. F. N., FINSINGER, W., GOBET, E., PINI, R., SCHWEIZER, A., VALSECCHI, V., AMMANN, B. 2005: Migration and population expansion of Abies, Fagus, Picea and Quercus since 15000 years in and across the Alps, based on pollenpercentage threshold values. Quaternary Science Reviews 24, 645-680.

WICK L., MÖHL, A. 2006: The mid-Holocene extinction of silver fir (Abies alba) in the Southern Alps: a consequence of forest fires? Palaeobotanical records and forest simulations. Vegetation History and Archaeobotany $15,435-444$. 
WILMANNS, O. 2001: Exkursionsführer Schwarzwald. Eine Einführung in Landschaft und Vegetation. Ulmer, Stuttgart.

WILMANNS, O. 2009: Zur Landschaftsökologie des Mittleren Schwarzwaldes - Von der Römerzeit zum Frühmittelalter. In: Kleiber, W.
(Ed.): Tarodunum/Zarten - Brigobannis/Hüfingen. Kelten, Galloromanen und frühe Alemannen im Schwarzwald in interdisziplinärer Sicht. Abhandlungen der Geistes- und Sozialwissenschaftlichen Klasse 2009/4, Mainz/Stuttgart, 77-102. 